\title{
Process Writing in a Product-Oriented Context: Challenges and Possibilities ${ }^{1}$
}

\author{
Produção textual como um processo \\ em um contexto centrado no produto: \\ desafios e possibilidades
}

Isabela de Freitas Villas Boas

Casa Thomas Jefferson

Brasília - Distrito Federal / Brasil

\begin{abstract}
This case study analyzed to what extent localized process writing pedagogy is applicable and effective in an EFL context and how students respond and react to it. A class of 16 intermediate-level teenage students in an ELT Institute in Brazil was selected. A carefully planned project on process-based writing was followed, and students' performance in and reactions to each stage of the process were analyzed. Concurrently, the study also investigated the teaching of writing in students' native language - Portuguese - in their regular schools. It could be concluded that the teaching of writing in the regular schools focuses more on the process than on the product and that a pedagogical approach focused on the process in the EFL classroom can serve to fill in the gaps left by the students' experiences with writing in L1.
\end{abstract}

KEYWORDS: process-based writing pedagogy, L1 writing pedagogy, EFL, peer revision.

RESUMO: Este estudo de caso analisou a aplicabilidade de uma pedagogia para o ensino da escrita como um processo em um contexto de ensino de inglês como língua estrangeira e como os estudantes reagiram e responderam a essa metodologia de ensino. Um grupo de 16 adolescentes de nível intermediário em uma instituição particular de ensino de inglês foi selecionado. Foi seguido um projeto pedagógico em torno da escrita como um processo e as reaçóes e o desempenho dos alunos em cada um dos estágios do processo foi analisado. Ao mesmo tempo, investigou-se como se dá o ensino da escrita na língua materna nas escolas regulares dos alunos.

\footnotetext{
* isabela.villasboas@thomas.org.br

${ }^{1}$ Article based on part of the Doctoral Dissertation entitled $A$ Contribuição do Processo de Ensino-Aprendizagem de Produção Textual em Lingua Inglesa Para $O$ Letramento Do Aluno, presented at the School of Education, Universidade de Brasília, 2008, under the supervision of Stella Maris Bortoni-Ricardo.
} 
Concluiu-se que o ensino de produção textual nas escolas regulares enfoca mais o processo do que o produto e que uma pedagogia voltada para o processo nas aulas de inglês pode preencher lacunas deixadas nas experiências dos alunos com a escrita na língua materna.

PALAVRAS-CHAVES: ensino da escrita como um processo, ensino da escrita em língua materna, ensino de inglês como língua estrangeira, revisão por pares.

\section{Introduction}

Though the field of Second Language Writing is relatively new (FERRIS \& HEDGCOCK, 2005; MATSUDA, 2006), it has already surpassed the product versus process debate and reached a balanced perspective of composition theory. More student-centered pedagogical approaches have emerged, and academic writing is seen as a social act of communication. A balance has been formulated between process and product; courses emphasize both the classroom community and the participation of the student in the construction of his/her writing, as well as that of others, by means of peer review activities and collaborative projects (REID, 2001). Genres are also gaining a prominent role in the teaching of languages, in general, and writing, in specific cases (HAMMOND \& DEREWIANKA, 2001). Cope and Kalantzis (1993) favor the explicit teaching of genres, while Hyland (2003) argues that genre-based approaches can complement process-based writing.

In what has been coined the post-process era (ATKINSON, 2003), writing is seen as inherently social and transactional, involving mediation between the writer and the reader. As such, writing is a process which must be developed based on the world view, the schemata, and the interests of the reader. Writers understand and predict readers' expectations and shape their texts to meet them effectively. In this social-constructivist perspective, the audience and the discourse community determine knowledge, language, and the nature of the written discourse (FERRIS \& HEDGCOCK, 2005). The notion of post-process, though, is not the rejection of process, but rather the recognition of the multiplicity of L2 writing theories and pedagogies (MATSUDA, 2003).

Nevertheless, the teaching of writing still instigates several controversies. One of these regards the feedback students receive on their first draft: who should provide this feedback and how should it be shaped? Another controversy involves what types of texts should be worked on and to what extent the rhetorical patterns of the language should be taught (CASANAVE, 
2004). The students' learning objectives and the curriculum planners' ideology are major forces that affect the pedagogical decisions made (RAIMES, 2002).

Grabe (2001) summarizes the elements that ESL writing pedagogy should generally include: a) extensive practice; b) long-term curricular planning with a view to developing writing abilities; c) consistent exposition to a wide variety of texts and tasks; d) opportunities for appropriate feedback and revision; e) opportunities to discuss textual production and its revision visà-vis the proposed objectives; f) models of texts that present reasonable solutions to the tasks proposed; g) tasks that motivate the students. Again, the notion of process is clearly present in these premises.

However, the adoption of these principles in the teaching of EFL writing, and the resulting successes and failures, needs to be more extensively studied. The contextual factors that interfere with the teaching of EFL writing around the world have not yet been thoroughly documented. The body of research regarding the teaching of writing in EFL at the secondary level is scarce. Most of the studies involving the teaching and learning of L2 writing have been conducted with college-level ESL students, with a smaller set of studies involving college EFL writing, most coming from Hong Kong and Japan (MATSUDA, 2006). Fewer studies have focused on secondary students in Asia (LEE, 2004; LEE, 2008; PENNINGTON, BROCK \& YUE, 1996; TSUI \& NG, 2000) and addressed the implementation of process-based writing pedagogy in product-oriented writing classrooms, as reviewed by Lee (2010). In all of these, the second-language writing classes occurred in students' regular secondary schools. There are no studies with teenagers learning EFL writing in English-Language-Teaching (ELT) Institutes in Brazil, which students attend outside their regular school curriculum, and where the four skills are often integrated and students do not typically have a class dedicated exclusively to writing. Are the same premises applicable to the specific context outlined above? What are the contextual factors that influence the work done in the EFL classroom? As Matsuda (2006, p. 26-27) states, "for second language writing instruction to be most effective in various disciplinary and institutional contexts, it needs to reflect the findings of studies conducted in a wide variety of instructional contexts as well as disciplinary perspectives."

In addition, quantitative studies focused on micro-elements of the writing class prevail. The day-to-day procedural dimensions of the teaching of writing are rarely examined (HEDGCOCK, 2005). Casanave (2003, p. 85 ) defends the use of qualitative case studies "to explore the extraordinary diversity of L2 writers and writing contexts from an expanded sociopolitical 
perspective." Hence, it behooves us to try to understand the context in which second or foreign language writing instruction is inserted, just as it is also essential to investigate the writing class as a whole, the interplay between the pedagogy proposed, and how students perceive it and react to it, as well as their process of adaptation. This is in consonance with a complexity theory approach to second language development, in which the processes, rather than the outcomes per se, are of foremost interest (LARSEN-FREEMAN, 2011).

This case study contributes to the academic discussion by bringing insights from an under-researched age level in an under-researched writing context - teenagers' learning process-based writing in an English Language Teaching (ELT) institute in Brazil. Following a more holistic perspective, documenting the pedagogical work with writing for an entire year, and not just focusing on one aspect of the process-based writing class, e.g. peer revision or teacher feedback, as reported by Lee (2004 and 2008); Pennington, Brock $\&$ Yue (1996); or Tsui \& Ng (2000), for example, the present study sheds light on how secondary school students in a skills-integrated EFL class react, respond to, and adapt to process-based writing pedagogy as a whole. Students' sociopolitical contexts are also brought into the picture by way of an analysis of the concurrent writing pedagogy experienced by them in their L1 writing classes. As Larsen-Freeman (2011) argues, limiting the focal point of interest is a major challenge in studying complex systems. Since everything is interconnected, it is problematic to single out a component and separate it from the whole for examination.

\section{Context}

Even though students study English in Brazilian public schools since the fifth grade and in most private English schools since the first grade, the number of contact hours and students in the classroom, as well as the methodology used - grammar translation with a focus on reading strategies - make it unlikely that students will have gained more than basic-level fluency in the language by the end of high school. Most students finish high school without ever having written a single paragraph in English. It is therefore common for families who can afford it to enroll their children in ELT Institutes with more communicative and skills-integrated classes.

The ELT Institute where this research was conducted is located in Brasília, Brazil, where about $70 \%$ of the institute's students are school-age children and teens. The writing component of the curriculum is process-based, 
informed by the premises, as stated by Grabe (2001) and other second language writing authors (CAMPBELL, 1998; FERRIS \& HEDGCOCK, 2005; GRABE \& KAPLAN, 1996; KROLL, 2001; LIU \& HANSEN, 2002; NATION, 2009; RAIMES, 1998, 2002; REID, 2001; SEOW, 2002; SOKOLIK, 2003; WHITE \& ARNDT, 1991).

The teaching of writing has always been a challenge to teachers, because, as Brown (2001) states, it is perhaps the hardest skill to teach effectively and the one probably most neglected in ESL/EFL classrooms that are not exclusively dedicated to writing. Furthermore, students commonly present poor writing skills in general, leading to the assumption that the teaching of composition in the students' regular schools, in their L1 (Portuguese), is flawed.

Hence, there was a need to investigate what students' L1 writing instruction was really like, to find out how the students perceived these two differing learning environments, and, most importantly, to discover how they reacted to EFL process-based writing pedagogy. When importing teaching approaches from one context to another, one must consider the cultural forces that may affect them (CARNAGARAJAH, 2002). Moreover, as contemporary studies tend to make a more detailed analysis of contextual factors in their effort to understand complex phenomena, such as the learning of a language (VAN LIER, 2005), it was essential to understand the background experiences that students both bring and do not bring to their EFL class, and how these experiences shape their attitudes and behaviors.

\section{The study}

\subsection{Methodology and participants}

A case study was carried out with a class of 16 teenagers, aged 13-19, enrolled in the first and second levels of the intermediate course in the aforementioned ELT Institute. Each level consists of 64 contact hours over a period of 17 weeks - one semester. The students studied the first semester (level 3A) with one teacher and then the second (level 3B) with another, a standard procedure in the institute. A case study approach is recommended when one intends to study the changes that take place in a specific group over a longer period of time (VAN LIER, 2005), in this case, one year.

The intermediate course was chosen, because a greater emphasis is placed on writing in the courses from this level on, and students receive a separate composition grade. In each semester, students typically produce three pieces of 
writing in two drafts. The specific group was selected based on a questionnaire administered to all intermediate-level learners in the institute, which was intended to identify the three regular schools that most of the teenage students in the course attended. These three schools are hereinafter referred to as Schools A, B, and C. Of the three schools, the group selected was the school that had the largest number of students and had at least two students attending the same grade in each of the three schools, in this case, $9^{\text {th }}$ grade.

Out of the 16 students in the group in the ELT Institute, five attended School A, five attended School B, and two attended School C. Among the remaining four students, two attended a fourth and one a fifth school - not focused on in this study, as these schools are not as big as schools A, B, and C. The remaining student was already in college. These students went to their different schools in the morning and, twice a week in the afternoon, had English classes in the ELT Institute, with 100 contact-minutes each.

The major part of this study consists of the year-long case study with the group of 16 students, analyzing their experience with process-based writing in the EFL Institute. A secondary part consists of a shorter, two-month study in Schools A, B, and C, with a view to confirming or not the assumption that the approach used in the three major schools is more product-based and that the students have little, if any, experience, with process-based writing. For the classes observed in the regular schools to be comparable, the $9^{\text {th }}$ grade was chosen, given that, among the participants in the study, two were in the $9^{\text {th }}$ grade in each of the schools. These six students thus became the focus of the part of the study that investigated the writing pedagogy in the three major regular schools.

The two research questions were:

1) How do the students respond and react to the basic stages of process-based writing? The basic stages examined were planning, drafting, and feedback and revising (with an emphasis on peer revision), the recursive practices shared by most implementations of process-based pedagogy, according to Cumming (2003).

2) What is the teaching of L1 writing like in the three major regular schools attended by the students in the intermediate course? Is process-based writing adopted to any extent? 


\subsection{Procedure}

The ELT Institute adopts an integrated-skills methodology, so writing is one of the four skills studied, besides vocabulary and grammar. In each semester, students produce three compositions - one approximately every five weeks - and the pre, while, and post-writing processes extend for three classes. Hence, for the period of two semesters (totaling 34 weeks), the students' EFL classes focused on writing were observed - three classes for each writing cycle, consisting of the pre, while, and post-writing phases, totaling nine classes per semester and 18 over a one-year period. A journal was used to document the sequence of activities in class and register students' behaviors and reactions. The students' first and second drafts, the peer review sheets, and the recordings of the pairs' interactions in the final-open-ended peer review activity were also analyzed. Additional data collected included: a) written questionnaires ${ }^{2}$ (Appendixes 2-4); b) semi-structured face-to-face interviews (Appendix 1) with each of the 16 students; c) informal conversations with some students during their ten-minute class break or at the end of the class, aimed at verifying the observed assumptions; $\mathrm{d}$ ) interviews with the first and the second semester EFL teachers. Apart from the informal conversations, not recorded but summarized in writing directly afterwards, all the interviews were transcribed.

The main objective was to analyze how the students performed each task and how they reacted to the activities proposed so as to determine how the processbased writing pedagogy in the ELT Institute really worked on a day-to-day basis and what the conflicting forces were, as well as ascertain whether adopting such an approach was truly beneficial to students in this particular context.

As for the research in students' regular schools, carried out between week 18 and week 26 of the 34-week research cycle, data was collected by means of: a) interviews with the Portuguese teachers in the three schools, a writing center tutor in School C, and the Portuguese coordinator in schools $\mathrm{B}$ and $\mathrm{C} ; \mathrm{b}$ ) observation of a writing cycle around the argumentative text - two classes in each school, for the period of two to three weeks; b) analysis of six students' writing assignments in their $9^{\text {th }}$ grade Portuguese / Composition classes in their regular schools, two students from each school (School A, School B, and School C); c) specific questions to the six students about their

\footnotetext{
${ }^{2}$ Questionnaires and interviews were always conducted in students' native language so that they could express their opinions and feelings better. The answers presented here are translations.
} 
schools' L1 writing pedagogy during the longer interview described above; $d$ ) informal chats with the six students during the research period.

\section{Findings and Discussion}

The primary objective of this study was to investigate how students would react and respond to the basic stages of the writing process in an EFL class outside their regular schools, which will be analyzed and discussed more extensively below.

However, with a view to understanding students' actions and reactions in the EFL writing class in the ELT Institute, it was deemed necessary to also delve into their L1 writing experience and confirm or not the hypothesis that students had very little, if any, experience with process-based writing. The analysis of the regular schools will be presented first, as it provides data for the subsequent discussion of the EFL writing class.

\subsection{Understanding the context of students' L1 writing}

To contextualize the study, it was important to go beyond the EFL classroom and investigate students' educational experiences with writing in their mother tongue. The basic stages of the writing process - planning, drafting, and feedback and revising - were analyzed through class observations, interviews with the students attending the three schools, and analysis of the written artifacts of the six students attending the $9^{\text {th }}$ grade in the three schools, two students in each. The two classes observed in each of the three schools were focused on the Argumentative Essay. To determine whether the approach adopted in the regular schools leaned more towards the process or towards the product continuum, the stages of planning, drafting, and feedback and revising were chosen for the analysis, as they are the core stages of a process approach to writing. Due to space limitations and the impossibility of presenting all the data collected in this extensive study, a summary of the findings produced by triangulating the data is presented below.

\section{1) Planning}

With regard to planning, in none of the writing classes observed in the three schools was there a moment for the students to reflect specifically about the topic they were going to develop or to engage in any kind of activity that involved planning. The pre-writing emphasis was on the reading and analysis 
of texts of the same genre that students were to write on later, although about a different topic, and the study of the characteristics of that genre. In the three classes observed, there was a gap between analyzing the model and producing a new text. There was no time set aside for generating and organizing ideas.

Interviews with the students from the three schools also confirmed this observation and indicated that this was true for most, if not all, writing assignments. Students are identified only by their initials:

School A :

(Researcher) Tell me what you think is similar and what you think is different about the teaching of writing in your EFL school and in your regular school?

(M) The topics that the teacher proposes, the questions she asks us to answer. At school there is no such thing. The teacher assigns a topic and we write.

(LD) I always divide what I'm going to write about into paragraphs, the way I learned here in the EFL Institute. It helps me at school, because there they don't teach us how to do it.

School B:

(J) I don't work with planning in class. She gives an example, and we follow it.

School C:

(JO) At school they only give the topic, and we write.

(ME) We have a writing class with exercises. Then, at the end of the class, they assign the writing, and we have to bring it the next class.

Analysis of the students' notebooks corroborated the observation and the interviews, as there was no evidence of activities such as freewriting, outlining, or organizing information graphically.

\section{2) Drafting}

Interviews with the two students in School A and their writing teacher demonstrated that students are asked to rewrite their texts only when there is a need to. The teacher explained that she asked students with very poor texts to rewrite. She didn't see rewriting as a natural writing activity, aimed at even 
further improving a piece of writing that was already good, but rather, an activity carried out only by poor writers.

In School B, rewriting is not a common practice; according to the teacher, this is the stage in the process that the school has the least conditions to include, due to the number of students in class and groups each teacher has to teach. The Portuguese coordinator explained:

We have five Portuguese (Language Arts) classes a week, in which we have to teach grammar, reading, and writing. I wish we could spend more time teaching, writing, and working with the writing process, but the parents wouldn't accept it, because for them, to study Language Arts is to study grammatical terminology. ${ }^{3}$

The two students corroborated this finding by stating that they had never been asked to rewrite their texts at school, and the analysis of their writing notebooks also confirmed that none of the texts had been rewritten.

School C is the only one that has some sort of institutionalized drafting system. The student has to take at least one text per unit to the writing center; only the unsatisfactory texts are rewritten, and this rewriting seems to be restricted to "cleaning up".

(Writing center tutor) When there are too many spelling and punctuation mistakes or the student doesn't obey the paper margins, we ask them to rewrite their text. If they don't rewrite, they don't get the credit.

(ME) The writing center tutor corrects my spelling, punctuation, and formatting. The tutor doesn't usually provide suggestions on what to improve in content.

Furthermore, according to student JO, most students only take one of the six writings to the writing center, so even when there is a request for the text to be rewritten, it is only of one out of every six texts produced.

\section{3) Feedback and Revising}

Much like drafting, revising was not found to be a natural component of the process of producing texts in students' native language in their regular

\footnotetext{
${ }^{3}$ In Brazil, students are supposed to learn how to do sentence analysis. This is called a Grammar Class.
} 
schools. It was also found that many times students do not have interlocutors for all the texts they write. For example, in School A, students produced their argumentative texts in pairs. In this case, each student's interlocutor was the peer with whom he/she wrote the text. by himself. The teacher read and marked the text but provided no written feedback on it, only the grade according to the school's very simplified writing rubrics.

In one of the classes observed at School B, the teacher conducted a peer review activity in which students exchanged texts and gave oral feedback to each other, but without any specific advice. According to the two students in this class who took part in the study, it was the first time the teacher had conducted such an activity, which suggested that she might have done this to cause a good impression, given the fact that, in the interview with the teacher, one of the issues addressed had been process-based writing and peer review. Previously in the semester, students had worked with short stories by either ending or beginning a short story written especially for this project by a famous Brazilian writer. They worked in pairs and word-processed their texts at the computer lab. Student ML said,

I think they're going to publish a book with our stories. So far we have written three, but the teacher hasn't read them yet.

The students' writing instructor in School C works on the analysis of different genres in class and assigns the compositions for homework. In the observed class, for example, two argumentative texts in the textbook were interpreted and their rhetorical form was studied. To receive feedback on their writing, students have to make an appointment at the writing center to present at least one of the six assignments each term. Most students submit only one assignment, which is read only by the writing center tutor. The teacher himself only glances through the assignments and checkmarks them. He does not provide any feedback to students. He only marks students' writing on the writing test and the feedback given is only by means of a grade, rather than descriptive.

Another finding was that only checkmarks were registered in the six students' notebooks, where they had to keep their writings. There were no comments whatsoever, no markings at all. The feedback students received on their writing was their grades. 


\section{4) Overall findings}

In summary, the main focus of the L1 writing instruction in students' regular schools lies in the study and subsequent production of a variety of genres. On the other hand, there is little or no scaffolding for each writing task, nor is the writing process emphasized. The emphasis is clearly on the product. There is also a great emphasis placed on developing students' skills in writing for a test, even as early as the ninth grade, as they will all have to pass a university entrance examination when they finish the $12^{\text {th }}$ grade.

(T): What really counts in my school are the writing tests.

(teacher School C): They are naturally encouraged to bring their texts to the writing center, because, on the test, they have a writing task that is worth a lot of points. If they don't submit their writings to the writing center aide, they won't see the mistakes they are making.

(JO) Our writing test is worth the most points. The writings we produce during the unit count fewer points, and they only count if you did them or not.

\subsection{The writing process in the EFL classroom}

Given the product-oriented writing pedagogy experienced by students in their L1 writing classes, the primary objective was to investigate how the students responded and reacted to the basic stages of process-based writing informed by the principles adopted in the ELT institute, considering planning, drafting, and feedback and revising. Would the students find working with the writing process beneficial? Would they understand the importance of drafting and revising? Would they feel comfortable performing peer review activities? Would the focus on planning, which proved to be lacking in their L1 writing experience, be seen as beneficial? The planning, drafting, and feedback and revising stages are discussed separately below. Special emphasis is given to peer revision, as this aspect of process-based writing pedagogy proved to be the element that was most alien to the students in the study.

This main part of the study focused on all the 16 students in the group. Even though among the 16 students only six had taken part in the regular-school background study, described in the previous section, another six students also attended one of the three observed schools, though in higher grades, and had followed the same curriculum standards in their $9^{\text {th }}$ grade studies, as confirmed in the interview. Interviews with the other four students also corroborated the findings from the study in Schools A, B, and C that there is a greater emphasis on the writing 
product than on the writing process. Moreover, from a complex and dynamic systems perspective (LARSEN-FREEMAN, 2011), the 16 students were part of the group undergoing the process-writing experience; therefore, isolating only six students for observation would compromise the understanding of the complex adaptive system as a whole.

\section{1) Planning}

As shown above, students' $\mathrm{L} 1$ writing classes did not focus explicitly on the planning stage of the writing process. On the other hand, their EFL writing activities always placed a strong emphasis on the pre-writing stage by providing a model text to be analyzed by students and engaging them in different activities aimed at generating and organizing ideas, such as outlining, free writing, using graphic organizers, and debating. Students not only recognized the relevance of planning, but also spontaneously acknowledged the transferability of what they had learned about planning and organizing ideas in their EFL writing activities for their L1 writing. Below are some examples from students' responses to a questionnaire that asked what they had learned about the process of producing a text in their EFL writing class that they could use when they produced texts in Portuguese:

G- Vocabulary and the way the text is produced.

LG- We learned to organize our ideas better into introduction, development, and conclusion.

J- I learned to plan before writing my texts.

JU- Introduction, development, and conclusion; the introduction is very important, for it is what will catch the reader's attention (usually).

T- The organization of a text and of ideas.

LD- I learned how to organize my ideas to produce a good text.

C- Punctuation and coherence.

H- The text narrative; the structure; the development.

ME- I think I learned a lot regarding vocabulary. It's very important to know how to write in English. It will benefit us for the rest of our lives. Knowing the number of paragraphs, how to write an introduction, a good conclusion, this needs to be learned both in Portuguese and in English. 


\section{ML- Textstructures.}

JS- $\quad$ The structure of a text; how to put together a text.

Eleven students explicitly mentioned the organization of ideas, planning, or text structure as elements they had worked on and that would help them in their writing in general, in English or in Portuguese.

However, it is important to understand what led to the other five students to perceptions that were different from those of their peers. Students JO and $G$ said they had not learned anything that could be transferred to their writing in their native language. Both were students who showed engagement in the writing activities and who provided effective feedback to peers. Nonetheless, they were also among the youngest students in the group, leading to the hypothesis that their lack of maturity might have resulted in a limited awareness of their learning process.

The other three students' responses were compatible with their general attitude towards writing. Student $M$ presented a very negative attitude regarding the English class in general and writing in particular, especially in L1.

(M) Writing is boring. In school I have to write about things I will never need in my life, such as fiction. It would be better if we only learned grammar at school. (...) By learning grammar, I learn how to write.

His belief probably stems from the emphasis given to learning grammar in Language Arts classes in Brazil. Student E also mentioned that only the grammar would help him. He was the student who struggled the most with his writing, and though his texts improved significantly every time he wrote a second draft, he consistently failed to transfer the skills he had learned to the next assignment, always starting with very weak content and organization and improving only upon being clearly directed about what to do to improve. MR also did not feel that what she was learning in her L2 writing class could somehow be transferred to her L1 writing, as most of her colleagues did. She was very confident about her L1 skills and responded that the transfer occurred the other way around: what she learned about writing in L1 guided her writing in L2. Indeed, MR was a more mature writer than most students and obtained excellent results. 


\section{2) Drafting}

All the students' first and second drafts in the six assignments throughout the year were analyzed to verify if they had corrected the mistakes pointed out by the teacher and had followed the suggestions for improvement in content and organization provided by the teacher and the peer reviewer. This analysis showed that 13 of the 16 students benefitted from rewriting their texts in that they incorporated most of the suggestions offered by the peers and/or by the teachers. Only two students did not rewrite all their assignments: M, whose negative and confrontational attitude has already been discussed, and JS, one of the oldest students in class who was preparing for the university entrance examination and was overloaded at school.

A third student, ME, only partially benefitted from the drafting process. In all but the very last assignment of the year, she generally corrected the language use errors but refused to follow the peers' and/or teacher's suggestions for improvement of content and organization. In one of the face-to-face interviews, she responded that it was because she wanted to maintain her personal style. As an avid personal journal writer, ME believed she had to write as she pleased, without any rhetorical rules. It was only in the last assignment, which she improved substantially, that she realized that different genres require different and sometimes set patterns that she needed to adhere to in order to meet her audience's expectations.

Hence, students' general response to mandatory drafting was positive. In addition, in the individual interviews conducted, when asked which of the three stages of the process-based writing class they valued the most, 12 of the 16 students answered that it was the opportunity to rewrite and improve their texts. These findings support Ferris' (2002) statement that students benefit from rewriting their papers after receiving feedback from their instructors.

\section{3) Feedback and Revising}

In this study, specific emphasis was placed on peer revision in order to ascertain its effectiveness in the Brazilian context, where students do not usually engage in peer feedback of any sort and where 'saving face' is a strong cultural feature. It is known that for peer revision to work effectively, it has to be modeled and scaffolded for students (MENDONÇA \& JOHNSON, 1994; GRABE \& KAPLAN, 1996; BERG, 1999; LIU \& HANSEN, 2002; MIN, 2005). Moreover, peer revision should not be seen as a substitution of the teacher's response. It should be used in addition to it (CAULK, 1994). 
Following the recommendations above and considering that peer revision would be unfamiliar to most students, the activities were planned so as to progress in a continuum from very controlled to free.

The first activity of the year was based on a checklist that had been carefully explained and modeled with the students through collective analysis of an anonymous student's text prior to students' analysis of a peer's text. The activities over the year became more and more open-ended, culminating in a final activity in which students provided oral feedback to each other based on a guide that they themselves had developed. These interactions were recorded. The students' reactions to each assignment in class were observed and their performance in each activity was registered.

It was not easy to implement a peer review culture. In the first semester, most students complained every time the teacher said they were going to read each other's texts and give feedback; interviews with students revealed that nearly half of the students felt reluctant and embarrassed about sharing their writing with a peer. Student MR even said that giving feedback on students' texts is only the teacher's responsibility. She also demonstrated preference to working individually rather than in groups or pairs in her English classes. Students $\mathrm{G}$ and ME, especially, demonstrated great resistance to the tasks. ME tended to look at the observer angrily when the teacher mentioned they would revise each others' texts.

Students $\mathrm{M}$ and JS never managed to receive feedback from a peer because they never brought their text on time, always having to work with a peer on giving feedback to a third party. Two other students expressed their desire to talk to their peers about the text, rather than answer a peer review sheet. The first-semester teacher herself felt discouraged and, in the end-ofsemester interview, showed some reluctance towards the true effectiveness of peer review in her specific context.

I tried my best, but it was hard because the students are young and they are not used to this kind of work in their schools. It's not part of our culture. They don't like to criticize their peers' work or to give suggestions.

Despite the aforementioned drawbacks, most students performed the peer review tasks competently and were able to provide relevant feedback to their peers. Students M, ME, and MR were the ones who showed inconsistencies in their performance and a negative attitude towards the activities in class. 
(M) Why should I give feedback to my classmates if I don't want to become a teacher?

(E) I would prefer it the "basic" way: we write and the teacher corrects. That's all.

(MR) It's a waste of time and it's boring. Besides, I'm not totally sincere (when I give feedback to my peers).

(ME) I don't think anyone was truly honest in my writings because when the teacher marks them, there are many more errors.

(Researcher) But the purpose isn't to correct errors.

(ME) Okay, it is to read and understand, but sometimes they praise me, and I don't think they are sincere. And the teacher writes, "correct this, summarize this, replace this."

\section{On the other hand, positive attitudes could be seen in other students' comments:}

(GU) It's interesting to see how my classmates respond to the same assignment.

(JO) My classmates sometimes say something besides what the teacher says.

(G) I learn new things from my classmates. The teacher knows a lot, but my classmate knows a little more in some things, and I know a little more in others. We have the same level.

(J) If my classmates' writing is very good, I can see what I did wrong in mine. When I revise my classmates' writing and see what's wrong in their writing, I also see what's wrong in mine.

(C) I'm terrible at punctuation, so when I see someone using it correctly, I can see what I got wrong in mine.

(JS) We end up seeing the mistakes that most of us make, and then when we write again, we try to avoid them.

(H) You have a new perspective. You read a peer's text and you think, "I could have added this."

Students also showed a more positive attitude towards revising their peers' texts than towards having their texts revised. Seven students mentioned feeling embarrassed or anxious about seeing someone reading and assessing their texts, while only five expressed dissatisfaction or indifference regarding reading their peers' writing. 
(LG) The person who wrote the text gets embarrassed, so I don't think it's good for the person who wrote it, but for the person who is reviewing it's good, because by assessing others, they will be able to assess themselves.

In the second semester, on the other hand, there was a surprising qualitative leap in the students' attitude towards the peer review activities in class, and peer review became a natural element of the writing class. According to Larsen-Freeman (2011), behavioral change in complex systems can be gradual and linear or sudden and dramatic. In this case, the change in students' attitude was dramatic between the first and second semester, but it wasn't by chance. One of the possible reasons was that, upon being briefed about the peer review experience in the first semester, the second semester teacher decided to use a blog where students posted their texts, making the sharing of their writing with their peers more authentic. Also, while in the first semester peer review sheets were used, the peer review activities in the second semester were designed to be more interactive, with the second teacher's help. Student G, for example, who had been negative about the peer review activities in the first semester, engaged effectively in the activities in the second semester, especially because they matched G's extroverted personality.

Observations of the peer review activities and analyses of students' peer responses led to the conclusion that all students but $M$ and $M E$ were consistently able to provide adequate feedback to their peers in the second semester. More importantly, peer revision became a natural, transparent part of the class: on the due date of the last writing, a student asked the teacher when (not if?) they would do the peer review

Students' responses at the end of the year regarding what they had learned from doing peer review were categorized as follows:

a) Peer review as useless: I learned nothing. (2 students)

b) Peer review as a means to gauge my own writing: I learned that it is human to make mistakes. / I learned that everyone can make mistakes.

c) Peer review as a means to learn from the author: I improved regarding vocabulary, because when I didn't know a word, I asked the author of the text. / I learned new methods and vocabulary. / I learned words and the structure of the text.

d) Peer review as a means to improve my own writing: How to revise my own text. / Maybe to correct my own mistakes. / To notice our mistakes. 
e) Peer review as a collaborative activity: I learned how to work in a group and share my opinions and ideas with my peers. I I learned how important other people's help is to improve my own text.

An awareness of the process of internalization mentioned by Vygotsky (1986) is evident in the responses in categories $\mathrm{d}$ and e, for the students mentioned how reading their peers' texts helped them correct the errors in their own texts. A more advanced stage of awareness was demonstrated by the student who responded that he/she had learned to revise his/her own text, thus not using the expression "correct mistakes".

Another compelling piece of evidence of the general effectiveness of peer review is the fact that, in the final open-ended face-to-face conversation ${ }^{4}$ with their peers about their text, most students were able to establish a competent dialogue about their texts, providing sound suggestions for improvement, using feedback language such as:

- Your writing is good because you used a lot of connectors and good vocabulary, but you could give more examples.

- I think you should add more ideas in the second paragraph. It's too small.

- Your text is easy to read and your ideas are easy to understand.

- Your introduction is good, because you talk about other countries and cultures.

- Your conclusion is repetitive in relation to the introduction.

Even student $M$ managed to make ME see that she had to adhere to the rhetorical format of an expository essay:

- You weren't supposed to talk about yourself. You were supposed to explain how the different teenage tribes like to dress and behave.

It was also observed in the students' second drafts that they felt more comfortable about preserving the authorship of their texts when they received suggestions from peers rather than from the teachers. In addition, peer revision gave students the opportunity to know characteristics about each other that they wouldn't have known otherwise:

(T) I didn't know $(\mathrm{H})$ could use such a broad range of vocabulary.

${ }^{4}$ All conversations were recorded and transcribed. 
Finally, the second teacher had a paramount role in the effectiveness of peer review. While the first teacher performed the activities proposed responsibly, she did not seek solutions to the problems encountered along the way. Conversely, the second teacher showed greater commitment to making it work and sought creative solutions, leading students to also react more positively to peer revision, confirming Pennington, Brock, and Yue's (1996) findings of a cause-and-effect relationship between students and teachers regarding innovation.

All in all, the experience with peer revision in the EFL classroom showed that it can make the students more aware of the characteristics of an effective text, which can in turn contribute to the improvement of students' own texts, corroborating Tsui and Ng's (2000) conclusion that peer revision fosters a sense of audience, raises learners' awareness of their strengths and weaknesses, encourages collaborative learning, and strengthens the ownership of text. It also showed, though, that establishing a peer review culture comes with time and as a result of teacher patience, effort, and, above all, creativity to address the shortcomings. Furthermore, students' awareness of the role of peer review in their writing development and productive engagement in the activities do not happen overnight; therefore, peer review must be carried out consistently and in a well-scaffolded manner, going from very simple to more complex tasks, in order to achieve its goals in the long run.

\section{4) Overall findings}

At the end of the sixth and last assignment of the year, students evaluated the teaching of writing in the two semesters of the intermediate course and stated the positive and negative features. The question attempted to ascertain whether or not they would spontaneously refer to the stages of process writing and, if so, which ones.

Despite their lack of previous experience with process-based writing pedagogy, the vast majority of the students reacted positively to the pedagogical work with process-based writing throughout the year, even ME. The features of the writing instruction explicitly mentioned were the use of the class blog for the publishing of their writing, the opportunity to revise their texts, and, in one case, the opportunity to learn from peers.

J- $\quad$ It was positive to write the compositions and post them in the blog, for this way it became more practical and interesting. 
JO- It was very good. The positive points were the chance to learn by revising our texts and to understand better how to assess our errors and that of our classmates. Another positive point was posting the writing on the Internet.

E- Positive: the work with the blog; negative: my grades.

ME- There were positive and negative points. The positive points were that, in each text, we learned more vocabulary, and we had the chance to correct our mistakes. The negative point is that we have little time.

C- It was positive to rewrite our texts, and it was negative when the texts became longer.

G- It's important for our learning, because with composition we learn to write better.

Student MR appreciated the anonymous student's text analysis activity but disliked giving feedback to a "real" peer.

It was positive to read a composition and evaluate whether it was good or bad, but it was negative to read the compositions of our classmates.

She also said in an interview that she did not think students were competent enough to give feedback on each other's writing.

Going back to the research question, of the sixteen students in the group, eleven (69\%) responded and reacted positively to all the stages of the writing process in that they showed engagement in the pre-writing activities, rewrote all their texts during the two semesters, and participated either very well or at least adequately in the peer review activities. They also demonstrated appreciation of process-based writing pedagogy in the individual interviews and questionnaires. On the other hand, five students demonstrated a resistance or lack of commitment to at least one of the three stages. Their attitude and beliefs possibly stem from their experiences in their L1 writing classes, which diverge in focus from EFL writing pedagogy.

\section{Conclusion and final remarks}

The year-long study showed that teenagers in an EFL skills-integrated class in Brazil can respond positively to process-based writing pedagogy, although many of the stages addressed are alien to students' previous experiences with writing. Most students performed all the tasks successfully and benefitted from working with planning, drafting, and revising. However, 
the process-based writing pedagogy did not affect all students in the same way, nor did all the students engage in all the stages of the writing process. Peer revision was particularly difficult to implement but showed promising results, despite a few students' consistent resistance. Nevertheless, the EFL processbased writing pedagogy was successful with the vast majority of the students, who recognized its effectiveness and even recognized the transferability of skills from the EFL writing context to their L1 writing context.

The study of the educational context in which students work with writing outside the EFL class indeed helped in the understanding and interpretation of some of their behaviors and opinions regarding the writing instruction in the ELT institute throughout the year. The resistance to nontraditional assessment practices, such as peer revision, was due to the fact that such a type of collaborative activity was not part of the students' background experiences with writing at their regular schools. For MR and E, for example, it is the teacher's job to give students feedback on their writing, not the classmates'. Peer revision was not consonant with her existing frame of what a writing class should be like. For M, Language Arts was about learning grammar, not about writing, and this attitude was transferred to his nonchalant behavior towards the writing assignments in his EFL class.

The fact that a few students sometimes ignored the teacher's or the peers' feedback on content and organization of ideas can be the result of their not commonly receiving feedback on their writing at all, and when they do, it focuses more on language use, handwriting, and formatting. In addition, students rarely, if ever, have to rewrite their texts. When they do, as is the case in schools A and C, it is because the text is considered poor. Hence, they have not developed the notion that every text, no matter how good its first draft is, can be improved, and that experienced writers always revise their writing.

There were three other major divergences between the EFL writing class and students' composition classes at school. In the EFL class, allowing students to produce their texts using a computer and even creating a writing blog for the class was a completely novel procedure, given that at their regular schools they had to handwrite their texts as a means of preparing them for the university entrance exam. Another element that confused the students was when they were advised by their EFL teacher or peers to expand their content. In their writing classes at their regular school, they commonly have a number of lines limit. Thus, they are not used to being advised to add or expand ideas. On the other hand, students study and produce a much wider variety of genres than in their EFL writing, suggesting a need for a review of the EFL writing curriculum. 
The main objective of this study was to describe and analyze how students responded and reacted to process-based writing pedagogy in their EFL classes over a one-year period in order to ascertain its effectiveness in such a context. The research also identified the divergences between the EFL writing pedagogy and the L1 writing pedagogy in students' regular schools, with a view to interpreting their behaviors, opinions, and productions in their EFL writing classes, as well as identifying the gaps left in the L1 writing pedagogy, which can possibly be filled by EFL writing classes. The findings show that it takes time for students to adapt to pedagogical practices that have not been experienced by them previously but that over time they are able to adapt. Though social-political barriers to the full adoption of process-based writing does exist, they do not justify its non-adoption, especially since it proved to be beneficial to and even appreciated by most students in the long run. The implications of this study are that persistence in using a process-oriented approach to the teaching of EFL writing in Brazil can bring very positive results, even if it is not part of students' frames, and that these results might even transfer into students' writing in their L1, especially regarding macro elements of writing, such as cohesion and coherence. However, this is a non-linear, messy process that requires specific teaching skills, hence warranting the need for further studies of second language writing in teacher development programs.

This study does, however, have a number of limitations. As a case study, it cannot be extrapolated to other contexts. Future studies need to encompass other educational contexts and grade levels in Brazil. Moreover, we cannot claim that students' writing improved as a result of the process-based writing methodology. With a focus on the pedagogical practices, this study did not include the analysis of students' writings or the adoption of statistical procedures to measure progress or the comparison of their first and second language writing to identify instances of transfer. Future studies can benefit from this additional quantitative stance.

\section{References}

ATKINSON. D. L2 Writing and culture in the post-process era: Introduction. In: Journal of Second Language Writing, vol. 12, issue 1, New York, NY: March, 2003. p. 49-63.

BERG, E. C. The effects of trained peer response on ESL students' revision types and writing quality. In: Journal of Second Language Writing, vol. 8, issue 3, New York, NY: September, 1999. p. 215-241. 
BROWN, H. D. Teaching by principles: An interactive approach to language pedagogy. White Plains: Pearson Education, 2001.

CAMPBELL, C. Teaching second-language writing: Interaction with text. Boston: Heinle \& Heinle, 1998.

CANAGARAJAH, A.S. Critical academic writing and multilingual students. Ann Arbor: The University of Michigan Press, 2002.

CASANAVE, C. P. Looking ahead to more socio-politically oriented case study research in L2 writing scholarship (But should it be called "post process"?). In: Journal of Second Language Writing, vol. 12, issue 1, New York, NY: March, 2003. p. 85-102.

CASANAVE, C. P. Controversies in second language writing: dilemmas and decisions in research and instruction. Ann Arbor: The University of Michigan Press, 2004. CAULK, N. Comparing teacher and student responses to written work. In: TESOL Quarterly, vol. 28, issue 1, Alexandria, VA: March, 1994. 181-188

COPE, B.; KALANTZIS, M. Introduction: How a genre approach to literacy can transform the way writing is taught. In: COPE, B.; KALANTZIS, M.(Ed.). The powers of literacy. London: Falmer, 1993. p. 1-21.

CUMMING, A. Experienced ESL/EFL writing instructors' conceptualizations of their teaching: Curriculum options and their implications. In: KROLL, B. (Ed). Second language writing: Research insights for the classroom. Cambridge: Cambridge University Press, 2003. p. 71-91.

FERRIS, D. Treatment of error. Ann Arbor: The University of Michigan Press, 2002. FERRIS, D.; HEDGCOCK, J. Teaching ESL Composition: Purpose, process, and practice. $2^{\text {nd }}$ ed. Mahwah: Erlbaum, 2005.

GRABE, W. Reading-writing relations: theoretical perspectives and instructional practices. In: BELCHER, D.; HIRVELA, A. (Orgs.). Linking literacies Perspectives on $L 2$ reading-writing connections. Ann Arbor: The University of Michigan Press, 2001. p. 15-47.

GRABE, W.; KAPLAN, R. B. Theory and practice of writing. London: Longman, 1996.

HAMMOND, J.; DEREWIANKA, B. Genre. In: CARTER, R.; NUNAN, D. (Ed.). The Cambridge guide to teaching English to speakers of other languages. Cambridge: Cambridge University Press, 2001. p. 186-193.

HEDGCOCK, J.S. Taking stock of research and pedagogy in L2 writing. In: HINKEL, E. (Ed.) Handbook of research in second language teaching and learning. New Jersey: Lawrence Erlbaum Associates, 2005. p. 597-613. 
HYLAND, K. Genre-based pedagogies: A social response to process. In: Journal of Second Language Writing, vol. 12, issue 1, New York, NY: March, 2003. 17-29 KROLL, B. Considerations for teaching an ESL/EFL writing course. In: CELCEMURCIA, M. (Ed.), Teaching English as a second or foreign language. $3^{\text {rd }} \mathrm{ed}$. Boston: Heinle, 2001. p. 219-240.

LARSEN-FREEMAN, D. A complexity theory approach to second language development / acquisition. In: ATKINSON, D. (Ed.). Alternative Approaches to Second Language Acquisition. New York: Routledge, 2011. p. 48-72.

LEE, I. Error correction in L2 secondary writing classrooms: The case of Hong Kong. In: Journal of Second Language Writing, vol. 13, issue 4, New York, NY: December, 2004. p. 285-312.

LEE, I. Understanding teachers' written feedback practices in Hong Kong secondary classrooms. In Journal of Second Language Writing, vol. 17, issue 2, New York, NY: June 2008, 69-85.

LEE, I. Writing teacher education and teacher learning: Testimonies of four EFL teachers. In: Journal of Second Language Writing, vol. 19, issue 3, New York, NY: September, 2010. p. 143-157.

LIU, J.; HANSEN, J. G. Peer response in second language writing classrooms. Ann Arbor: The University of Michigan Press, 2002.

MATSUDA, P.K. Process and post-process: a discursive issue. In: Journal of Second Language Writing, vol. 12, issue 1, New York, NY: March, 2003. p. 65-83

MATSUDA, P. K. Second language writing in the twentieth century. In: MATSUDA, P.K.; COX, M.; JORDAN, J.; ORTMEIER-HOOPER, C. (Orgs.). Second language writing in the composition classroom - A critical sourcebook. Boston: Bedford / St. Martin's, 2006, p. 14-30.

MENDONÇA, C.; JOHNSON, D. E. Peer review negotiations: revision activities in ESL writing instruction. In: TESOL Quarterly, vol. 28, issue 4, Alexandria, VA: December, 1994. p. 745-769.

MIN, H. T. Training students to become effective peer reviewers. In: System, vol. 33, issue 2, 2005. p. 293-308.

PENNINGTON, M.C.; BROCK, M.N.; YUE, F. Explaining Hong Kong students' response to process writing: An exploration of causes and outcomes. In: Journal of Second Language Writing, vol. 5, number 3, 1996. p. 227-252.

NATION, I.S.P. Teaching ESL/EFL Reading and Writing. New York: Routledge, 2009.

RAIMES, A. Teaching writing. In: Annual Review of Applied Linguistics, vol. 18, Cambridge: March, 1998. p. 142-167. 
RAIMES, A. Ten steps in planning a writing course and training teachers of writing. In: RICHARDS, J.; RENAYA, W. A. (Orgs.). Methodology in language teaching: an anthology of current practice. Cambridge: Cambridge University Press, 2002. p. 306-314.

REID, J. Writing. In: CARTER, R.; NUNAN, D. (Orgs.). The Cambridge guide to teaching English to speakers of other languages. Cambridge: Cambridge University Press, 2001. p. 28-33.

SEOW, A. The writing process and process writing. In: RICHARDS, J., RENAYA, W. A. (Orgs.). Methodology in language teaching: an anthology of current practice. Cambridge: Cambridge University Press, 2002. p. 315-320.

SOKOLIK, M. Writing. In: NUNAN, D. (Ed.). Practical English language teaching. New York: McGraw Hill Contemporary, 2003. p. 87-108.

TSUI, A. B. M.; NG, M. Do secondary L2 writers benefit from peer comments? In: Journal of Second Language Writing, vol. 9, number 2, 2000. p. 147-170.

VAN LIER, L. Case study. In: HINKEL, E (Ed.). Handbook of research in second language teaching and learning. Mahwah, NJ Lawrence Erlbaum Associates, 2005. p. 195-207.

VYGOTSKY, L.S. Thought and language. London: Longman, 1986.

WHITE, E.; ARNDT, V. Process writing. New York: Longman, 1991. 


\section{APPENDIX 1 - Guiding questions for semi-structured interviews with students}

1) How do you like your writing classes at school? And at the ELT institute? Do you consider yourself a good writer?

2) In which ways are your writing classes at school similar to the ones at the ELT institute and in which ways are they different?

3) Describe the most recent writing assignment you had at school, giving details about what you did before you wrote, who read your text, how it was assessed, etc.

4) What have you learned in your EFL writing class that you have used or can use in your L1 writing?

5) What have you learned in your writing classes at school that you resort to when you write for your EFL class?

6) We have been working with peer revision this semester. Have you done peer revision before? What do you think about this type of activity? Why do you think the class sometimes complains about doing peer revision?

(Other personalized questions were asked based on my observations of students' attitudes in class)

\section{APPENDIX 2 - Questionnaire administered at the end of the first semester}

1) In the first peer review activity, you used a checklist to mark the features that were present in the text. In the second, besides the checklist, you also had to ask questions to help your peer improve the content of the writing. In the third, you answered openended questions.

a. Why do you think this sequence of activities was used?

b. What did you think about each one?

c. Which one was easier and which one was the hardest?

2) How did you feel about reading your peer's texts?

3) How did you feel about your peer reading your texts?

4) What did you learn from the peer review activities?

5) Are these activities worthwhile? Why?

6) Do you have any suggestions on how to improve the peer review activities? 


\section{APPENDIX 3 - Questionnaire administered after the first peer review activity of the second semester, aimed at assessing students' reactions to giving oral, rather than written, feedback and using the blog (new procedures introduced)}

1) Did you like publishing your text in the blog?

2) What did you think about reading your peers' texts in the blog?

3) What did you think about providing oral feedback to your peer?

4) Last semester you gave written feedback to your peers, and this time you did it orally. Which way do you think works better?

5) Was your peer able to give good suggestions to improve your text?

6) Were you able to give your peer good suggestions to improve his/her text?

7) Do you think that your ability to analyze your peer's text and identify the positive and negative features has improved since last semester?

\section{APPENDIX 4 - Questionnaire administered at the end of the second semester}

1) How would you assess the work done this year at the ELT Institute with regard to writing? What was positive and what was negative?

2) How would you assess the work done this year at your regular school with regard to writing? What was positive and what was negative?

3) What did you learn about the writing process in the ELT Institute that you use or could use when you produce texts in Portuguese?

Data de submissão: 02/09/2013. Data de aprovação: 18/02/2014. 